\title{
MANAGER SATISFACTION IN USING THE ENTERPRISE RESOURCE PLANNING (ERP) SYSTEM AND THE MANAGERIAL PERFORMANCE
}

\author{
Weli \\ Faculty of Economics \\ Atma Jaya Catholic University of Indonesia, Jakarta \\ weli.imbiri@gmail.com
}

\begin{abstract}
This study is aimed to test the manager's satisfaction of the managers using the ERP and to test the influence of job satisfaction towards the performance in the decision process by the manager. The measurement of the satisfaction towards the ERP system will be conducted using the end user's satisfaction computing model (EUCS), using the content, accuracy, formal ease of use, and timelines attributes (Doll and Torkzadeh, 1988). Whereas, the performance is measured using the instrument which was developed by Nicolaou (2000) consisting of 2 (two) question items about the reporting and continuing control, 7 (seven) items of questions adopted from the study results of Spathis and Constantinides (2004). The data were collected through a survey using questionnaires distributed to companies that have used the ERP system. The data analysis used the Partial Least Square method with SmartPLS program. The results show that the concept of EUCS has a conformation and there is a significant effect between the ERP system user satisfaction with the manager's performance, especially in the decision making process. This result contributes to the concept of EUCS and supports previous research related to end user satisfaction.
\end{abstract}

Keywords: Enterprise Resource Planning, ERP, Information System, End User Computing Satisfaction, EUCS, manager performance.

\section{INTRODUCTION}

Nowadays the use of the Enterprise Resource Planning (ERP) system has experienced a rapid growth, also in Indonesia. SAP Indonesia as one of ERP vendor has succeeded for the IV 2009's quarter, to have a significant growth rate of $30 \%$, compared with 2008, that is, 47 companies have become new customers. Other information that has been reported in Kompas of 11 July 2009 is, that large companies in Indonesia have used the ERP system with the SAP vendors having reached more than 250 SAP companies and according the SAP Indonesia report, until 2012, the SAP users have reached more than 800 companies.

The growth of the ERP system users is not free from the wishes of the company to integrate all business functions so that streamlining data processing will occur via a centralized database. Besides, the hope, being the basis of the use of the ERP is to create an efficient and an effective business organization process, increasing the ability in making managerial decisions, and monitoring company's performance. Similarly, according to Sajadi et al. (2008) that the use of the ERP systems may affect the effectiveness of information systems through improved managers decision-making processes, internal controls, and improving the quality of financial reporting and facilitates transaction processing companies. Furthermore, an effective information system is expected to improve the quality of decisions, and improving the company's performance.

Previous studies have reported both success stories and failures in the process of implementing ERP systems. Several reasons were found from the literature that many ERP projects fail because of complexity of the implementation processes, the lack of conformity between the management project and the ERP system and the business organization's process, the lack of users skilled, the coordination 
issues, the lack in planning and project management, as well as consultant's quality. However, previous study in using system has shown the importance of the system user's satisfaction. The user satisfaction was determined by the user system satisfaction towards factors of the success of the system implementation. The interaction between user and implemented system will result in the perception of the user alone. The user's perception is directed towards the satisfaction or on the contrary, towards the no satisfaction of the system.

Considering the aim of the use of the ERP is create the integrated flow of the information, it is expected that the information produced by the system will be more qualified. The information quality becomes an important weapon for decision makers in solving business problems. Therefore, this study will examine the satisfaction of manager of the ERP system user and whether the satisfaction towards the use of the ERP system has an influence towards the company's performance, especially in the decision making process by the manager. The satisfaction measurement towards the ERP system is conducted through the end user's computing satisfaction (EUCS) model, using the content, accuracy, format, ease of use, and timelines attributes (Doll and Torkzadeh, 1988).

The EUCS model to measure the satisfaction of the user of the ERP has already been conducted by Hees and Hightower (2002), Rose (2006), Deng et al. (2008), and Mitakos et al. (2010). In general, the EUCS analytical report for the ERP system shows that the EUCS concept can also be used for the ERP system, as well as to other systems at the previous studies.

Although the study using the EUCS have already been conducted many times before, however, all those studies have only confirmed the measurement model for the system user's satisfaction and have not yet seen the system user's influence towards the organization, especially in the decision making process by the management. Therefore, this study will analyze the satisfaction measurement of the ERP system user and to test this satisfaction influence towards the organization, especially, at the decision making process by the manager. Therefore, the aim of this study is as follows:

1. Conducting an analysis on the Content, Accuracy, Format, Ease of Use and Timeliness as the makers of the satisfaction factors for the ERP users.

2. To analyze the influence of the manager's satisfaction of the use of the ERP system towards the manager performance in the decision making.

Whereas the theoretical framework, regarding the relationship between the variables, is reflected in Figure 1.

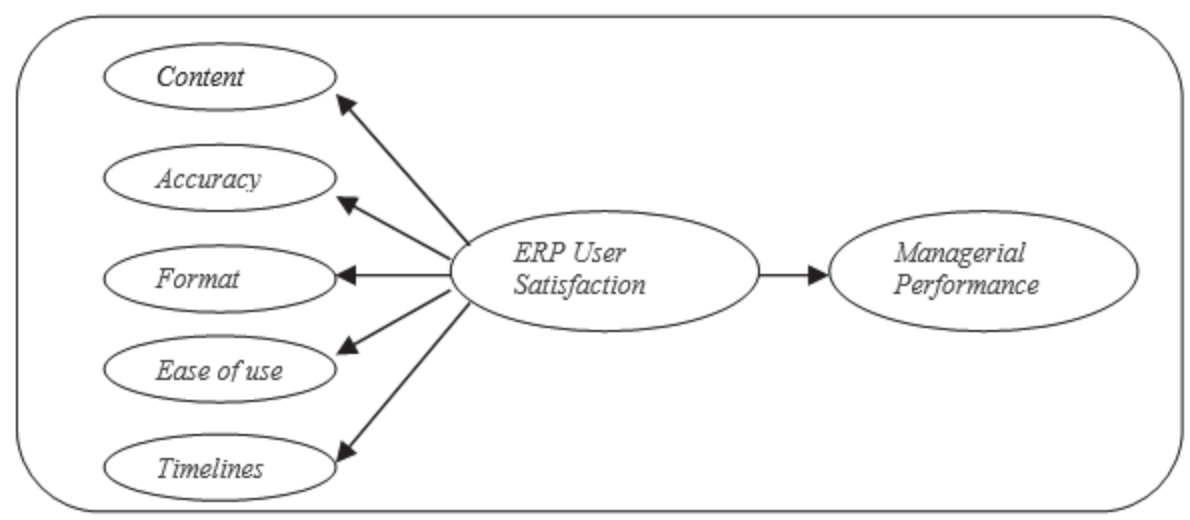

Figure 1 Research model 


\section{LITERATURE REVIEW AND THE HYPOTHETICAL FORMULATION}

\section{The Satisfaction Measurement of The Information System User.}

The model to measure the system user's performance has been developed long time ago by the researchers in the field of the information system. One of the models that are frequently used is the End User Competing Satisfaction (EUCS). The EUCS was developed in 1988 by Doll and Torkzadeh to measure the computer's end user satisfaction. Doll and Torkzadeh have found five factors (content, accuracy, format, ease of use and timeliness) strongly measured the satisfaction of the end-user, so that this instrument became the right instrument to measure the end-user's satisfaction.

Another model to measure the system user's satisfaction is the successful information system, which has developed since the beginning of 1990 (DeLone, and Mclean, 1992). This model has further developed, parallel with the many studies conducted in testing the success of the system (Delone, 2003). The satisfaction model of the system user as developed by Delone (2003) values that the satisfaction in using the information by relating the satisfaction of the system user with the usage and the organization's performance. The higher the satisfaction rate towards the new implemented system, the higher the intention to use it and at the end will make the individual's and organization's performance better and more efficient.

User satisfaction can be defined as the level of user confidence over an information system use that is available to meet their needs for information. When users use the system they will evaluate the various aspects of the use based on their experience compared to the expectations over the system. Although the study about the satisfaction of the end user has already been developed since the last decade, however this study has still drawn the researcher's as well as practitioner's interest (Khalifa and Liu, 2003). Since the Delone and Mclean (1992, 2003) model was developed, many researchers have continued investigating the information system, extra construct, and the different points of view.

The test of the user's satisfaction at the of the ERP system has also been carried out, among others by Hees and Hightower (2002), Roses (2006), Deng et al. (2008) and Mitakos et al (2010). Hees and Hightower (2002) have proposed a framework to test the ERP system users using the equity theory. The aim of their study is to look into the attitudes of the users to complete the framework of the satisfaction of the system user model. Roses (2006) has tested the antecedent factor of the ERP system users satisfaction, using the information system's success and the EUCS model. The result of the study has confirmed that the application of the EUCS model can be used in the application of the ERP system.

Deng et al. (2008) have analyzed the multi-group variance towards the EUCS instrument for the use of the Enterprise system in five countries (US, Western Europe, Saudi Arabia, India and Taiwan). The analysis report has indicated that the EUCS instrument has provided a measurement result that is equal among the five countries. Hence, conclusion can be derived that the EUCS instrument can be globally used. Mitakos et al. (2010) has connected the success of the implementation and operation of ERP with the user. They have tested the demographic of the individuals (the department in which the user works, the user position in the organization, the education level, age, computer experience, gender) who influence the satisfaction of the ERP system user by adding the self-efficacy factor. However, not a single individual demographic factor proposed, have proofed that it can satisfy the ERP system user.

Based on previous studies, especially at the ERP system and the accounting information, this study will test again the ERP system user's satisfaction model using the End User Computing Satisfaction (EUCS) as proposed by Doll \& Torkzadeh (1988). The result of above mentioned studies indicates that the EUCS instrument was a measurement in which the validity has been tested and has often been used as an instrument to measure the effectiveness of the system in the study of the Accounting Information System. Another reason being the base of the use of the EUCS measurement is that the ERP system is designed to solve the information disintegration by consolidating all business operations to be an 
integrated system. The integration of the system is hoped to produce better information as seen from the perspective of the content, accuracy, format, ease of use and timeliness. Therefore, the hypothesis formula in this study is as follows:

H1: There is a direct influence between Content from the output of the ERP system and the manager's satisfaction using the ERP system.

H2: There is a direct influence between accuracy of the output of the ERP system and the manager's satisfaction using the ERP system.

H3: There is a direct influence between the form of the output system of the ERP and the manager's satisfaction using the ERP system.

H4: There is a direct influence between the ease of use of the ERP system and the manager's decision using the ERP system.

H5: There is a direct influence between the Timeliness of the output of the ERP system the manager's satisfaction.

\section{The Enterprise Resource Planning (ERP) system user's satisfaction and the Managerial Performance.}

The user's satisfaction at the previous studies was identical with the valuation of the effectiveness of an information system (DeLone and McLean, 1992). The system user's satisfaction in interacting with the system can be seen from their experience with the information output as produced by the system. The produced physical output by the system can be valued through the content, accuracy, format, ease of use and timeliness. Further, is the user's satisfaction towards the output quality in accordance with what is in need, whether the output system can increase the work productivity, increase the work performance, and increase the control towards the decision, related with the resulting information. Therefore, it is hoped that the information result can make the decision making process more effective, the information reach easier to interpret, and better understood and the distribution of information to the sections or to the related functions can be upgraded (Ugboma, 2004).

Further, according to Kim (1988), an effective system depends on the user's perception regarding the information quality result, whereas the quality of the information is dependent on the reliability, the reporting form, the timeliness, and relevance for the decision making. Further, Nicolaou (2000) has defined the perception about the effectiveness of a system as seen from the perspective of the decision maker regarding the information output, which is originated from the transaction process which is adapted to their needs in the coordination and the management controlling activities.

According to Sajady et al. (2008), the information system effectiveness is also dependent on the decision maker's perception towards the usefulness of the information, resulted from the system, to fulfill the information needs in the operational process, the managerial report, the budget, and the organizational control. The result of Sajadi et al. (2008) study has indicated that the implementation of the information system will result in betterment of the decision making process by the manager, the internal control and the financial reporting quality, and the facility of the company's transaction process. Further, in this study the evaluation of the managerial performance influence towards the information system user's satisfaction is focused towards the information usefulness for the users. The measurement is derived from the value of the user's satisfaction towards the information quality, consisting of the form, content, and the presentation presented in the ERP system.

Based on above mentioned observation, this study will also value the influence of the manager satisfaction in using the ERP system, as measured with the EUCS towards the manager's performance, especially in the process of the decision making. This can be reached because the ERP system has the characteristics of integrating all business functions. With the existence of the information system we 
can hope that that it will increase the information to those using it as well as that it will also improve the dispatch of the information to those using it besides, it will also improve the consistence of the data and the information resulted from the system. Hence, the measurement of the user's satisfaction will become relevant in value the managerial performance effectiveness. Therefore, the measurement of the user's satisfaction will become more relevant to value the managerial performance effectiveness. Further, the hope, as the basis for the performance increase is the believe that the information technology equipment can catch information and spread it more rapidly to the whole organization to help the individual to do work and to make better decision (Arnold, 2006). Since one of the goals for using the ERP system is the data integration, the system will provide data that can be used collectively by all individuals in the organization. Besides, it is expected that the system will create an up to date data (Nah et al., 2001). Therefore, there are 6 hypothesis formulations, as follows:

H6: There is direct influence between the manager's satisfaction using the ERP system and the manager's performance, especially in the decision making activities.

\section{RESEARCH METHOD}

The research population is the ERP system users at the manager level from all companies in Jakarta that have already used the ERP system. However, because the list of companies that have been using the ERP system is not available, so that it is not possible to have a sampling framework and therefore the sampling can not be conducted randomly. The collection of information about the company is done by searching the search engine (Google). After the information about the company is collected, the next stage is to ask the willingness of the company to collaborate in the survey and who can be contacted to fill the questioners.

The data collection process was done during 4 (four) month, that is, from beginning October 2010 until February 2011. The data collection was conducted by sending the questioners via the post office service, e-mail and visiting the related company directly. Until the time limit, the rate of return via the post office, and e-mail have only reached 12 copies, while directly sent only 38 copies. This is far from the expectation. Therefore, the researcher has extended the time limit for collecting the data until April 2011. The last result of the collection process, only 18 copies were collected via the post office and email, and 53 copies were sent directly, hence, the total was 71 copies.

\begin{tabular}{|l|r|r|r|}
\hline \multicolumn{1}{|c|}{ Method } & Sent & Received & \multicolumn{1}{c|}{ Response Rate } \\
\hline Via Post & 162 & 9 & $5,56 \%$ \\
\hline Directly Visit & 54 & 53 & $98,15 \%$ \\
\hline Via E-mail & 52 & 9 & $17,31 \%$ \\
\hline Total & 268 & 71 & $26,49 \%$ \\
\hline
\end{tabular}

Table 1. Response Rate

\section{The validity instrument}

Although the EUCS instrument is much used in previous studies, and the validity has been tested, because the instrument is translated into the Bahasa Indonesia, hence it is important to test the instrument in the Bahasa Indonesia. Therefore, before the survey in the field took place, the researcher has asked the help of some experts to read and to provide input regarding the instrument that have been developed. This pre-test is useful to understand whether the questioner is applicable, can be read, and be understood, as seen from the perspective of the format, the time needed to fill, as well as from the point of the questioner, whether is has already included the expected goal. Questioners that have already been developed were sent to three experts who understand the product and the application of the ERP 
system of the company. From the review of these experts a small revision has been done relating to the use of the sentences.

Apart from the importance of the validation and reliability of the EUCS instrument, this study will examine all five variables of the EUCS instrument with the factor analysis, using the SPSS 16 program, where the result will be presented at the next section.

\section{Operational Variable and Measurement}

The variable that forms the ERP system user's satisfaction is adopted from the End User Computing Satisfaction (EUCS) concept as proposed by Doll \& Torkzadeh (1988), in which the ERP system user's satisfaction is influenced by 5 variables, that are Content, Accuracy, Format, Ease of Use and Timelines. The measurement of the the five constructs is using the seven points Likert scale, from not very agreed up to very agreed. The questions items of every construct are presented in the following Table 2.

\begin{tabular}{|c|c|}
\hline Code & Explanation \\
\hline Content & $\begin{array}{l}\text { Used to measure the ERP user's perception regarding how far the ERP output } \\
\text { system is on hand in accordance with their needs, consisting of } 4 \text { (four) questions } \\
\text { items. }\end{array}$ \\
\hline $\mathrm{C} 1$ & The ERP system provides the right information as needed. \\
\hline $\mathrm{C} 2$ & The ERP system content fulfill the needs \\
\hline C3 & The ERP system presents the reports exactly as requested \\
\hline $\mathrm{C} 4$ & The ERP system provides the needed information \\
\hline Accuracy & $\begin{array}{l}\text { is used to measure the ERP system user' perception regarding the accuracy of the } \\
\text { available ERP system output consisting of } 2 \text { question items }\end{array}$ \\
\hline A1 & The ERP system used is accurate \\
\hline A2 & The accuracy of the ERP output system as presented is satisfactory \\
\hline Format & $\begin{array}{l}\text { Used to measure the ERP user's perception regarding the format of the output of the } \\
\text { ERP system on hand consisting of } 2 \text { question items }\end{array}$ \\
\hline F1 & The ERP output system is shown in an usefull format \\
\hline $\mathrm{F} 2$ & The presented information by the ERP system is very clear. \\
\hline Ease of Use & $\begin{array}{l}\text { is used to measure the ERP user's perception regarding the easiness of the use of } \\
\text { the ERP system, consisting of } 2 \text { questions items }\end{array}$ \\
\hline E1 & The ERP system is user friendly \\
\hline $\mathrm{F} 2$ & The ERP system is very easy to use \\
\hline Timelines & $\begin{array}{l}\text { is used to measure the ERP user's perception regarding the timelines to get } \\
\text { information from the ERP system output consisting of } 2 \text { (two) questions items. }\end{array}$ \\
\hline $\mathrm{T} 2$ & The ERP system provides the best information \\
\hline T1 & The needed information can be timely used \\
\hline
\end{tabular}

Source: Doll \& Torkzadeh (1988)

Table 2. EUCS Construct

\section{Managerial Performance}

The managerial performance is used to measure the manager's perception who uses the ERP system regarding the manager's task in making decisions. Previous studies Nicolaou (2000) has developed the measurement for test the effectiveness system consisting of 2 (two) question items about reporting and extended controlling. In accordance with the objectives of this study the measurement of managerial performance will adopt Nicolaou (2000) instruments. 
Besides, it is also measured through 7 (seven) question items, adopted from the Spathis and Constantinides (2004) study result. The question items for managerial performance is presented in Table 3:

\begin{tabular}{ll}
\hline KM1 & $\begin{array}{l}\text { The use of the ERP system makes that the controlling report, such as the daily or the weekly } \\
\text { report occasionally available, systematic, and in order. }\end{array}$ \\
\hline KM2 & $\begin{array}{l}\text { In general, the ERP system provides important information, which is useful for the } \\
\text { continuing control of the decisions and activities }\end{array}$ \\
\hline KM3 & Use of the ERP system has increase the financial reporting quality \\
\hline KM4 & Use of the ERP system has increase the decision making process \\
\hline KM5 & $\begin{array}{l}\text { Use of the ERP system has made the company's information system more accurate and can } \\
\text { be easily assessed }\end{array}$ \\
\hline KM6 & Use of the ERP system has decreased the information processing cost \\
\hline KM7 & Use of the ERP system has increased the information/visibility flow \\
\hline KM8 & Use of the ERP system has increased the flexibility \\
\hline KM9 & Use of the ERP system has increased the company's integration \\
\hline
\end{tabular}

Source: Nicolaou (2000), Spathis and Constantinides (2004)

Table 3. Managerial Performance Construct

\section{RESULT}

\section{Respondent profile}

The process of the data shows that most of the correspondents who have answered the questioners have managerial positions in the information technology and in accounting (see table 4). They have been in these positions for about 3 years (see table 5), and have been working in miscellaneous industries (automotive, cable, electronic, see table 6). Whereas the majority of the ERP products used, were originated from the SAP vendors (see table 8). 


\begin{tabular}{|l|l|l|}
\hline Position & Total & Percentage \\
\hline Branch Manager & 1 & $1.4 \%$ \\
\hline Corporate Secretary & 1 & $1.4 \%$ \\
\hline Director & 5 & $7 \%$ \\
\hline Finance Director & 2 & $2.8 \%$ \\
\hline Accounting Manager & 18 & $25.4 \%$ \\
\hline Group Manager & 1 & $1.4 \%$ \\
\hline HRD Manager & 6 & $8.5 \%$ \\
\hline IT Manager & 19 & $26.8 \%$ \\
\hline Finance Manager & 2 & $2.8 \%$ \\
\hline Marketing Manager & 1 & $1.4 \%$ \\
\hline Project Manager & 3 & $4.2 \%$ \\
\hline Relation Manager & 3 & $4.2 \%$ \\
\hline Sales Manager & 2 & $2.8 \%$ \\
\hline Sipil Manager & 1 & $1.4 \%$ \\
\hline Treasury Manager & 2 & $2.8 \%$ \\
\hline Senior Manager & 2 & $2.8 \%$ \\
\hline Supervisor & 2 & $2.8 \%$ \\
\hline Total & 71 & $100 \%$ \\
\hline
\end{tabular}

Table 4. Respondent Profile Position

\begin{tabular}{|l|l|l|}
\hline Tenure & Total & Percentage \\
\hline < 3 year & 34 & $47.9 \%$ \\
\hline 3 - 5 year & 14 & $19.7 \%$ \\
\hline 5 - 10 year & 13 & $18.3 \%$ \\
\hline 10 - 15 year & 6 & $8.5 \%$ \\
\hline$>15$ year & 4 & $5.6 \%$ \\
\hline Total & 71 & $100 \%$ \\
\hline
\end{tabular}

Table 5. Position Tenure 


\begin{tabular}{|l|c|c|}
\hline \multicolumn{1}{|c|}{ Industry } & Total & Percentage \\
\hline Agriculture & 3 & $4 \%$ \\
\hline Mining & 4 & $6 \%$ \\
\hline Basic Industry and Chemicals & 7 & $10 \%$ \\
\hline Miscellaneous Industry (automotive, cable, electronic) & 15 & $21 \%$ \\
\hline Consumer Goods Industry & 8 & $11 \%$ \\
\hline Property, Real Estate and Building Construction & 9 & $13 \%$ \\
\hline Infrastructure, Utilities \& Transportation & 8 & $11 \%$ \\
\hline Finance & 8 & $11 \%$ \\
\hline Trade, Service\&Investment & 9 & $13 \%$ \\
\hline Total & 71 & $100 \%$ \\
\hline
\end{tabular}

Table 6. Industries

\section{Non-Response Bias Test}

As presented at table 7, the result of the non-response bias test between the group of 50 respondents that have responded earlier, (October 2010 - February 2011) and the group who have responded at the end of 21 respondents (March 2011 - April 2011), the p-value >0,05. Therefore, the conclusion is that there are no differences between the groups for the testing the group that has responded earlier and the group that has responded at the end. Therefore, this data is applicable for further tests.

\begin{tabular}{|l|l|c|c|}
\hline \multirow{2}{*}{ Description } & & \multicolumn{2}{|c|}{ Variable } \\
\cline { 3 - 4 } & & SATIS & KM \\
\hline \multirow{2}{*}{ Earlier (N=50) } & Mean & 0.0741 & .0099 \\
\cline { 2 - 4 } & Standard Deviation & 1.0515 & 1.131 \\
\hline \multirow{2}{*}{ Late (N=21) } & Mean & -0.176 & -0.238 \\
\cline { 2 - 4 } & Standard Deviation & 0.891 & 0.645 \\
\hline & Probability & 0.343 & 0.875 \\
\hline
\end{tabular}

Table 7. Non-Response Bias-Test

\section{Factor Analysis}

This study has used Structural Equation Model the alternative method Partial Least Square (PLS). The program to be used is the SmartPLS 2.0 M3, which is derived from http://www.smartpls.de (Ringle, Wende, and Will, 2005). The reason for the use of this Partial Least Square (PLS) is the small sample size. Besides because it can estimate a complex model with a small sample, Partial Least Square (PLS) does not assume that the data must be normally distributed. Further, the use of the PLS is also appropriate if the conceptual model and its measurement has not yet been rightly developed or its characteristic is still in the exploration stage of the theoretical development (Ghozali, 2011). However, the use of the PLS, are limited to exploratory model so that the results of this research is to proposed a model of user satisfaction and managerial performance. Testing hypotheses using PLS will be done in 
three stages. At the next part a hypothetical test will be conducted, using the PLS. The test will be carry out in three phases, that is:

\begin{tabular}{|l|l|l|l|l|l|}
\hline Vendor & Total & Persentage & Vendor & Total & Persentage \\
\hline Agresso & 1 & $1.4 \%$ & Oracle & 7 & $9.9 \%$ \\
\hline Averis & 1 & $1.4 \%$ & Oracle, erp eracomp & 1 & $1.4 \%$ \\
\hline Erasoft & 1 & $1.4 \%$ & Peoplesoft & 3 & $4.2 \%$ \\
\hline ERP Eracomp & 1 & $1.4 \%$ & Platinum & 1 & $1.4 \%$ \\
\hline Fova System & 1 & $1.4 \%$ & SAP & 32 & $45.1 \%$ \\
\hline IFS & 4 & $5.6 \%$ & SAP, Dynamix AX & 1 & $1.4 \%$ \\
\hline IFS, MAS & 1 & $1.4 \%$ & SAP, JD Edwards & 1 & $1.4 \%$ \\
\hline IFS, SAP & 1 & $1.4 \%$ & SUN SYSTEMS & 2 & $2.8 \%$ \\
\hline In house & 4 & $5.6 \%$ & Sunfish MCS & 1 & $1.4 \%$ \\
\hline MIKROTEK INDONESIA & 1 & $1.4 \%$ & WD ERP SYS & 1 & $1.4 \%$ \\
\hline & & & WD ERP SYS-MY & & \\
\hline Mincom & 3 & $4.2 \%$ & SYS & 1 & $1.4 \%$ \\
\hline MS D Axapta & 1 & $1.4 \%$ & Grand Total & 71 & $100 \%$ \\
\hline
\end{tabular}

Table 8. ERP Vendor

\section{Phase 1: The Test of the Measurement Model (outer model)}

\section{The Convergent Validity Test}

Convergent validity measures the consistency of the loading factor for many operations tested, using the loading factor value towards the construct, which is statistically significant. In this study, the loading factor value used is above 0.7 as proposed by Chin, (1998) and Ghozali, (2011). Besides that, each construction must have the Average Variance Extracted (AVT) above 0.5 (Fornell and Larcker, 1981). At Figure 2, it can be observed all loading factor values above 0.7 and the result of the SmartPLS test, which shows that the AVE value of above 0.5, so that the whole indicator can be applied to test the hypothesis. 


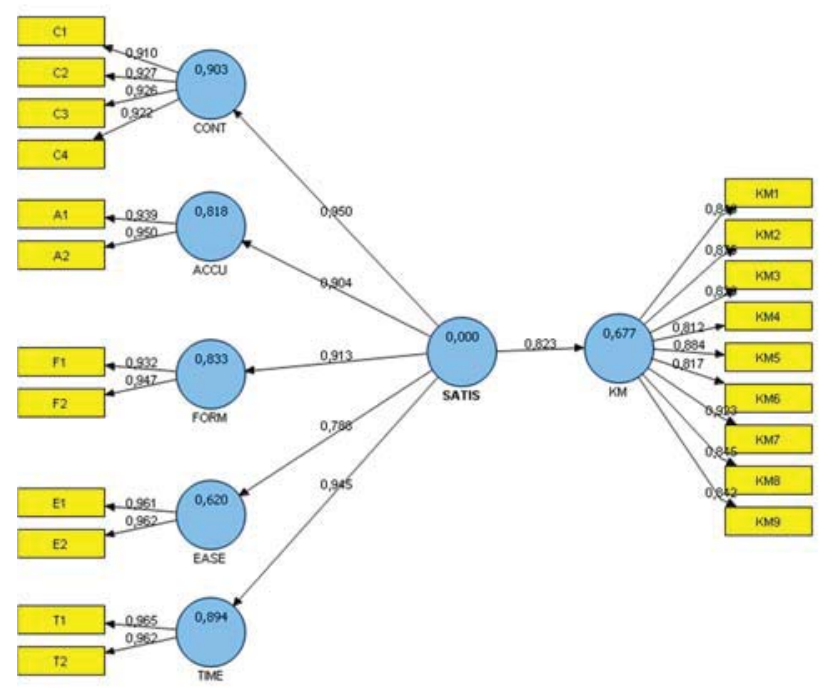

Source: Output Smart PLS 2.0 M3

Figure 2. The Convergent Validity Research Model

\begin{tabular}{|l|l|l|l|l|l|}
\hline & Original Sample & T Statistics & & Original Sample & T Statistics \\
\hline A1 <- ACCU & 0,9389 & 43,7384 & F1 -> SATIS & 0,8047 & 15,4149 \\
\hline A1 -> SATIS & 0,8116 & 13,5616 & F2 <- FORM & 0,9469 & 83,2522 \\
\hline A2 <- ACCU & 0,9499 & 90,4288 & F2 -> SATIS & 0,9056 & 40,3067 \\
\hline A2 -> SATIS & 0,8933 & 31,5605 & KM1 <- KM & 0,846 & 26,9722 \\
\hline C1 <- CONT & 0,9096 & 34,0322 & KM2 <- KM & 0,8745 & 28,9261 \\
\hline C1 - SATIS & 0,8975 & 33,3979 & KM3 <- KM & 0,8294 & 29,8634 \\
\hline C2 <- CONT & 0,9269 & 41,2957 & KM4 <- KM & 0,8123 & 17,8409 \\
\hline C2 -> SATIS & 0,8526 & 17,9641 & KM5 <- KM & 0,8839 & 28,931 \\
\hline C3 <- CONT & 0,9257 & 44,342 & KM6 <- KM & 0,8165 & 15,6028 \\
\hline C3 -> SATIS & 0,8521 & 16,8733 & KM7 <- KM & 0,9233 & 38,2907 \\
\hline C4 <- CONT & 0,9215 & 39,5405 & KM8 <- KM & 0,8449 & 20,6689 \\
\hline C4 -> SATIS & 0,895 & 30,161 & KM9 <- KM & 0,842 & 19,8449 \\
\hline E1 <- EASE & 0,9613 & 80,3301 & T1 <- TIME & 0,9648 & 89,4489 \\
\hline E1 -> SATIS & 0,7533 & 11,2113 & T1 - SATIS & 0,9286 & 50,186 \\
\hline E2 <- EASE & 0,9621 & 83,4785 & T2 <- TIME & 0,9619 & 72,9349 \\
\hline E2 -> SATIS & 0,7616 & 11,0604 & T2 -> SATIS & 0,8922 & 29,261 \\
\hline F1 <- FORM & 0,9322 & 42,7493 & & & \\
\hline
\end{tabular}

Table 9. Loading Factor 


\section{The Discriminant Validity Test}

The valuation of the discriminant validity at this study was conducted using 2 (two) methods. First, the valuation was carry out based on the cross loading measurement with the construct, if the construct correlation using the item is greater than the other construct. This means that the latent construct will predict better the measurement at their block than the measurement in other blocks. The result of the cross loading test shows that all the loading factor value of each indicator is larger than the measurement at other constructs. The conclusion of this analysis is that each latent construct will be able to predict the measurement of their block better so that this research model has a good discriminant validity value.

\begin{tabular}{|c|r|r|r|r|r|r|}
\hline & \multicolumn{1}{|c|}{ ACCU } & \multicolumn{1}{c|}{ CONT } & \multicolumn{1}{c|}{ EASE } & \multicolumn{1}{c|}{ FORM } & \multicolumn{1}{c|}{ KM } & \multicolumn{1}{c|}{ TIME } \\
\hline A1 & $\mathbf{0 , 9 3 9}$ & 0,742 & 0,512 & 0,732 & 0,612 & 0,763 \\
\hline A2 & $\mathbf{0 , 9 5 0}$ & 0,811 & 0,596 & 0,849 & 0,684 & 0,848 \\
\hline C1 & 0,782 & $\mathbf{0 , 9 1 0}$ & 0,628 & 0,830 & 0,758 & 0,859 \\
\hline C2 & 0,743 & $\mathbf{0 , 9 2 7}$ & 0,546 & 0,715 & 0,767 & 0,824 \\
\hline C4 & 0,695 & $\mathbf{0 , 9 2 6}$ & 0,616 & 0,687 & 0,821 & 0,791 \\
\hline E1 & 0,811 & $\mathbf{0 , 9 2 2}$ & 0,645 & 0,786 & 0,690 & 0,893 \\
\hline E2 & 0,541 & 0,647 & $\mathbf{0 , 9 6 1}$ & 0,663 & 0,639 & 0,618 \\
\hline F1 & 0,718 & 0,627 & $\mathbf{0 , 9 6 2}$ & 0,681 & 0,633 & 0,618 \\
\hline F2 & 0,854 & 0,834 & 0,656 & $\mathbf{0 , 9 3 2}$ & 0,563 & 0,710 \\
\hline KM1 & 0,696 & 0,805 & 0,595 & 0,947 & 0,681 & 0,837 \\
\hline KM2 & 0,700 & 0,845 & 0,574 & 0,695 & $\mathbf{0 , 8 4 6}$ & 0,735 \\
\hline KM3 & 0,541 & 0,621 & 0,539 & 0,519 & $\mathbf{0 , 8 2 9}$ & 0,834 \\
\hline KM4 & 0,505 & 0,628 & 0,525 & 0,502 & $\mathbf{0 , 8 1 2}$ & 0,615 \\
\hline KM5 & 0,664 & 0,708 & 0,633 & 0,649 & $\mathbf{0 , 8 8 4}$ & 0,695 \\
\hline KM6 & 0,471 & 0,681 & 0,621 & 0,445 & $\mathbf{0 , 8 1 7}$ & 0,638 \\
\hline KM7 & 0,588 & 0,704 & 0,558 & 0,586 & $\mathbf{0 , 9 2 3}$ & 0,662 \\
\hline KM8 & 0,465 & 0,639 & 0,534 & 0,439 & $\mathbf{0 , 8 4 5}$ & 0,531 \\
\hline KM9 & 0,580 & 0,631 & 0,479 & 0,542 & $\mathbf{0 , 8 4 2}$ & 0,591 \\
\hline T1 & 0,838 & 0,900 & 0,637 & 0,814 & 0,775 & $\mathbf{0 , 9 6 5}$ \\
\hline T2 & 0,809 & 0,863 & 0,600 & 0,779 & 0,717 & $\mathbf{0 , 9 6 2}$ \\
\hline
\end{tabular}

Table 10. Cross Loading

The second valuation was carry out by comparing the square root of Average Variation Extracted (AVE) of each construct with the correlation between the construct and other construct in the model. The result of the calculation shows that the square root of AVE value is larger than the construct's correlation value. Therefore, is can be said that the model in general has a good discriminant validity (Fornell and Larcker, 1981). 


\begin{tabular}{ccclcl}
\hline & AVE & $\sqrt{ }$ AVE & Composite Reliability & R Square & Cronbachs Alpha \\
\hline ACCU & 0,892 & 0,944 & 0,943 & 0,818 & 0,879 \\
CONT & 0,848 & 0,921 & 0,957 & 0,903 & 0,940 \\
EASE & 0,925 & 0,962 & 0,961 & 0,620 & 0,919 \\
FORM & 0,883 & 0,940 & 0,938 & 0,833 & 0,868 \\
KM & 0,728 & 0,853 & 0,960 & 0,677 & 0,953 \\
TIME & 0,928 & 0,963 & 0,963 & 0,894 & 0,923 \\
\hline
\end{tabular}

Table 11. Validity Measurement

\section{Composite Reliability Value}

Composite reliability is a block indicator that measures a construct reflexively. The Composite reliability with a value of more than 0.7 shows that the internal consistency is good. The result of the Smart PLS of 2.0M3, as seen at Table 11, shows that the composite reliability value of the whole construct is above 0.7 . Therefore, we can conclude that all constructs have a good internal consistency.

All measurements of above measurement model show that a value that fulfill the measurement criteria. Therefore, we can conclude that all indicators that have already been revised, can be used to test the hypothesis. All items that explain the construct of this study have a relatively high reliability.

\section{Phase 2: Structural Model Test (Inner Model)}

After testing the research model (Outer Model), we further conduct a test towards the structural model. This test is meant to evaluate the relationship between the constructs that have been proposed at this study's hypothesis. Information that shows how good the structural model predicted can be observed from the R square value, which is the goodness-fit test model, to explain the percentage of the construct variation towards the whole model.

The result of the test using the SmartPLS for the whole level 1 construct (Accuracy, Content, Format, Timelines) has shown that a fairly strong explanation power, that is larger that $67 \%$, except for Ease of Use construct which is only 62\%, however, this value is quite substantial (Chin,1998). Also, for the $\mathrm{R}$ square value, the managerial performance (KM) shows a fairly high explanation power, which is $67.7 \%$. This means that the EUCS construct is applicable to measure the user's satisfaction of the ERP system. Besides, the construct of the user's satisfaction together explain as much as $67.7 \%$ of the variation towards the managerial satisfaction.

\section{Phase 3: Hypothetical test}

The hypothetical test was conducted through the coefficient parameter and the statistical $\mathrm{t}$ significant value. Conducting the bootstrapping procedure of 300 samples a coefficient path, that shows the power of the relationship between the two constructs. The coefficient path value to relate the construct ACCU, CONT, EASE, FORM, and TIME towards the whole SATIS construct is above 0,7 and it is significant at $\mathrm{p}=0,05$ with a $t$ value higher than 1.96 . Therefore, hypothesis 1 up to hypothesis 5 which conclude that accuracy, content, ease of use and timelines influence directly the satisfaction of the ERP system user is accepted. The results of the tests of hypothesis 1 up to hypothesis 5 have proven that the whole EUCS construct is applicable to measure the user's satisfaction of ERP. Also, the track coefficient value to influence the user's satisfaction (SATIS) towards the managerial performance (KM) is 0.823 and it is significant at $\mathrm{p}=0.05$ with a $\mathrm{t}$ value higher than 1.96 , that is 17.471 . Therefore, hypothesis 6 that proposes that there is a direct influence between the satisfaction of the ERP user and the managerial 
performance is accepted. This means that the ERP user's satisfaction influences directly the managerial performance.

\begin{tabular}{|l|c|c|}
\hline & Original Sample & T Statistics \\
\hline SATIS -> ACCU & 0,905 & 29,702 \\
\hline SATIS -> CONT & 0,950 & 55,219 \\
\hline SATIS -> EASE & 0,788 & 12,363 \\
\hline SATIS -> FORM & 0,913 & 40,101 \\
\hline SATIS -> KM & 0,823 & 17,471 \\
\hline SATIS -> TIME & 0,945 & 71,183 \\
\hline
\end{tabular}

Table 12. Coefficient Path

\section{DISCUSSION AND CONCLUSION}

This study is conducted with two aims, e.g. to analyze whether the Content, Accuracy, Format, Ease of Use, and Timeliness are measurements to measure the manager's satisfaction in using the ERP system, and whether there is a satisfaction influence of the manager in using the ERP system towards the manager's performance in the process of making decisions. The result of the data from 71 respondents shows that the construct of Content, Accuracy, Format, Ease of Use, and Timeliness influence significantly the construct of the manager's satisfaction using the ERP system. Based on this analytical result, and the test using the factor analysis, we can conclude that the concept as proposed by Doll \& Torkzadeh (1988) regarding the End User Computing Satisfaction (EUCS) can be used to measure the manager's satisfaction using the ERP system in this study.

The second analysis is to test the manager's satisfaction, using the ERP system, as measured by the Content, Accuracy, Format, Ease of Use and Timeliness towards the managerial performance, in which the managerial performance is explained through the questions items regarding the frequency and the reporting quality, the effectiveness of the monitoring activities, and the coordination by the management, the decision making process, the easiness to the information's availability, the reduction of information management, increase in the information flow, increasing the flexibility and the company's integration. Hence, from the result of the analysis, it can be concluded that in general, this study has supported the End User Computing Satisfaction (EUCS) concept as proposed by Doll \& Torkzadeh (1988), and other studies using the same concept and other information systems as well as the ERP system such as Hees and Hightower (2002), Roses (2006), Deng et al. (2008) and Mitakos et al. (2010). Therefore, this study has confirmed the EUCS concept for the ERP system, besides for other information systems, such as for previous studies. Besides, this study confirms the model as proposed in this study that the manager's satisfaction using the ERP system can influence the manager's performance in the decision making process.

\section{LIMITATION AND FUTURE AGENDA}

The limitedness of this study concerns the limitedness of the data, because this study could not used the data by random sampling because there is no information which shows that the quantity and the name of the companies which have already officially used the ERP system. Besides, the size of the samples of this study is also small, which is caused by the many companies that have not yet given the permission for the publication of information about the use of the ERP system for the public. The other limitedness is the managerial performance measurement, using the respondent's perception, is represented by only one respondent and satisfaction was measured quantitatively. Considering the 
limitedness of this study, the advice for the coming study is to use the case study method in order to delve more the viewpoint of the ultimate user of the organization as a whole, thus a satisfaction measured not only quantitatively but also qualitatively.

\section{REFERENCES}

Arnold, V. (2006) Behavioral research opportunities: Understanding the impact of enterprise systems. International Journal of Accounting Information Systems, 7(1), 7-17.

Chin, W. W. (1998) Commentary: Issues and opinion on structural equation modeling. MIS Quarterly, vii-xvi.

DeLone, W. H., \& McLean, E. R. (1992) Information systems success: the quest for the dependent variable. Information Systems Research, 3(1), 60-95.

Delone, W. H. (2003) The DeLone and McLean model of information systems success: a ten-year update. Journal of Management Information Systems, 19(4), 9-30.

Deng, X., Doll, W. J., Al-Gahtani, S. S., Larsen, T. J., Pearson, J. M., \& Raghunathan, T. S. (2008) A cross-cultural analysis of the end-user computing satisfaction instrument: a multi-group invariance analysis. Information \& Management, 45(4), 211-220.

Doll, W. J., \& Torkzadeh, G. (1988) The measurement of end-user computing satisfaction. MIS Quarterly, 259-274.

Fornell, C., \& Larcker, D. F. (1981) Evaluating structural equation models with unobservable variables and measurement error. Journal of Marketing Research, 39-50.

Ghozali I. (2011) "Structural Equation Modeling: Metode Alternatif dengan Partial Least Square (PLS)". Edisi 3, Semarang: Badan Penerbit Universitas Diponegoro.

Hess, T. J., \& Hightower, R. (2002) Using Equity Theory to Understand User Satisfaction with ERP Systems: Extending and Advancing the Equity-Implementation Model. In Twenty-Third International Conference on Information Systems (ICIS) December.

Khalifa, Mohamed and Liu, Vanessa. (2003) The State of Research on Information System Satisfaction, Journal of Information Technology Theory and Application 5(4), Article 4.

Kim K. (1988) Organizational Coordination and Performance in Hospital Accounting Information Systems: An Empirical Investigation." The Accounting Review, 6: 85-99.

Mitakos, T., Almaliotis, I., \& Demerouti, A. (2010) An Auditing Approach for ERP Systems Examining Human Factors that Influence ERP User Satisfaction. Informatica Economica, 14, 78-92.

Nah, F.F.H., Lau J.L.S., dan Kuang, J. (2001) Critical Factors for Successful Implementation of Enterprise Systems, Business Process Management Journal, 7(3): 285--296.

Nicolaou A.I. (2000) A Contingency Model of Perceived Effectiveness in Accounting Information Systems: Organizational Coordination and Control Effects, International Journal of Accounting Information Systems, 1: 91--105.

Ringle C.M., Wende S., dan Will S. (2005) SmartPLS 2/0 (M3) Beta, Hamburg, http://ww.smartPLS.de. Accessed 29 September 2011.

Roses, L. K. (2006) Information System Success: Antecedents of End-User Satisfaction with ERP. EnANPAD-Encontro Nacional de Programas de Pós-Graduação em Administração.

Sajady H., Dastgir M., dan Nejad H.H. July (2008) Evaluation of The Effectiveness of Accounting Information Systems, International Journal of Information Science and Technology, 6 (2).

Spathis C. dan Constantinides S. (2004) Enterprise Resource Planning Systems' Impact on Accounting Processes, Business Process Management Journal, Vol. 10 (2):234--47. 
Ugboma E. (2004) Assuring Information Systems' Effectiveness through Data Integrity: Essential Guidelines for Information Systems Databases, Proceeding ISECON 2004, v21. 


\section{APPENDIX}

\section{CFA Result for EUCS Variable}

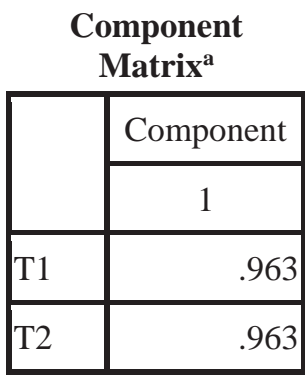

Extraction Method: Principal

Component

Analysis.

a. 1 components extracted.

\begin{tabular}{l}
\multicolumn{2}{c|}{$\begin{array}{c}\text { Component } \\
\text { Matrix }^{\mathbf{a}}\end{array}$} \\
\begin{tabular}{|l|r|}
\hline & Component \\
\cline { 2 - 2 } & 1 \\
\hline F1 & .940 \\
\hline F2 & .940 \\
\hline
\end{tabular}
\end{tabular}

Extraction Method: Principal

Component Analysis.

a. 1 components extracted.

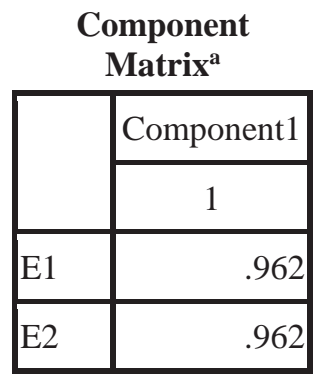

Extraction Method:

Principal

Component

Analysis.

a. 1 components extracted.

Component
Matrix $^{\mathbf{a}}$
\begin{tabular}{|l|r|}
\hline & Component1 \\
\cline { 2 - 2 } & 1 \\
\hline $\mathrm{C} 1$ & .907 \\
\hline $\mathrm{C} 2$ & .929 \\
\hline $\mathrm{C} 3$ & .928 \\
\hline $\mathrm{C} 4$ & .920 \\
\hline
\end{tabular}

Extraction Method:

Principal

Component

Analysis.

a. 1 components extracted.

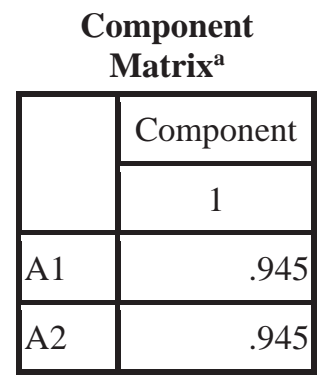

Extraction Method: Principal

Component

Analysis.

a. 1 components extracted.

\begin{tabular}{l}
\multicolumn{2}{c}{$\begin{array}{c}\text { Component } \\
\text { Matrix }^{\mathbf{a}}\end{array}$} \\
\begin{tabular}{|l|r|}
\hline & Component $^{\circ}$ \\
\cline { 2 - 2 } & 1 \\
\hline KM1 & .839 \\
\hline KM2 & .873 \\
\hline KM3 & .836 \\
\hline KM4 & .810 \\
\hline KM5 & .887 \\
\hline KM6 & .801 \\
\hline KM7 & .939 \\
\hline KM9 & .845 \\
\hline
\end{tabular}
\end{tabular}

Extraction Method: Principal

Component Analysis.

a. 1 components extracted. 